\title{
Effect of Biocyclic Humus Soil on Yield and Quality Parameters of Processing Tomato (Lycopersicon esculentum Mill.)
}

\author{
Lydia Dorothea EISENBACH ${ }^{1}$, Antigolena FOLINA ${ }^{1}$, Charikleia ZISI ${ }^{1}$, Ioannis ROUSSIS ${ }^{1}$, Ioanna TABAXI ${ }^{1}$, \\ Panayiota PAPASTYLIANOU ${ }^{1}$, Ioanna KAKABOUKI ${ }^{1}$, Aspasia EFTHIMIADOU ${ }^{2}$, Dimitrios J. BILALIS ${ }^{1 *}$ \\ ${ }^{1}$ Agricultural University of Athens, School of Agriculture, Engineering and Environmental Sciences, \\ Department of Crop Science, Laboratory of Agronomy, 75 Iera Odos Str., 11855 Athens, Greece. \\ ${ }^{2}$ Institute of Soil Science, Hellenic Agricultural Organization - Demeter, 1 S. Venizelou str., 14123 \\ Lycovrissi, Greece \\ *corresponding author: bilalisdimitrios@gmail.com
}

BulletinUASVM Horticulture 76(1) / 2019

Print ISSN 1843-5254, Electronic ISSN 1843-5394

DOI:10.15835/buasvmcn-hort: 2019.0001

\begin{abstract}
A field experiment was conducted to evaluate the effects of biocyclic humus soil, a newly found apparently carbon stabilized form of organic matter with significantly different characteristics from common composts or other forms of organic matter (humus), on yield and quality of processing tomato. The experiment was laid out in a completely randomized design with three replications and three fertilization treatments (untreated, inorganic fertilizer and biocyclic humus soil). The highest fruit yield (116.8 t/ha) was obtained by using biocyclic humus soil. There were no treatment effects on fruit firmness $\left(4.34-4.60 \mathrm{~kg} / \mathrm{cm}^{2}\right)$, total soluble solids $\left(4.29-4.76^{\circ} \mathrm{Brix}\right)$ and total acidity (0.25-0.31 g citric acid/100 g fruit) content of fruits. In conclusion, the tomato plants grown in biocyclic humus soil had $45 \%$ more yield than in conventional plots, and this big difference is probably related to the fact that the humus soil as a substrate provides an optimum environment for plant growth.
\end{abstract}

Keywords: Biocyclic humus soil, Biocyclic Vegan Standard, Heinz $3402 \mathrm{~F}_{1}$, processing tomato, total soluble solids

\section{Introduction}

Tomato (Lycopersicon esculentum Mill.) is the second economically most important vegetable worldwide after potato. The total cultivated area is about 4.8 million hectares with an average yield of 37 tons per hectare (FAOSTAT, 2018). A big part of the food processing industry has specialized in the processing of tomato products like tomato cans, juices, etc. The industrial processing of tomato started in 1850 and rapidly expanded after 1950 due to some important achievements in the breeding of new cultivars suitable for industrial processing. These new varieties and hybrids have a determinate growth, more compact flowering and fruit flesh, and higher content in the total soluble solids (TSS), so that the mechanical harvest is absolutely feasible (Miyao and Hartsough, 2010). In 2017, only 38 million tons of processing tomato were manufactured in the U.S.A. having the biggest production followed by China (WPTC, 2018). In general, the yield quantity and quality of tomato fruit are influenced by the interactions between cultivars, environmental factors such as temperature, light and water supply, and the composition of the nutrient solution and crop management (Bark et al., 2018; Le et al., 2018a, b).

Agriculture is facing enormous challenges regarding climate change. Not only because 


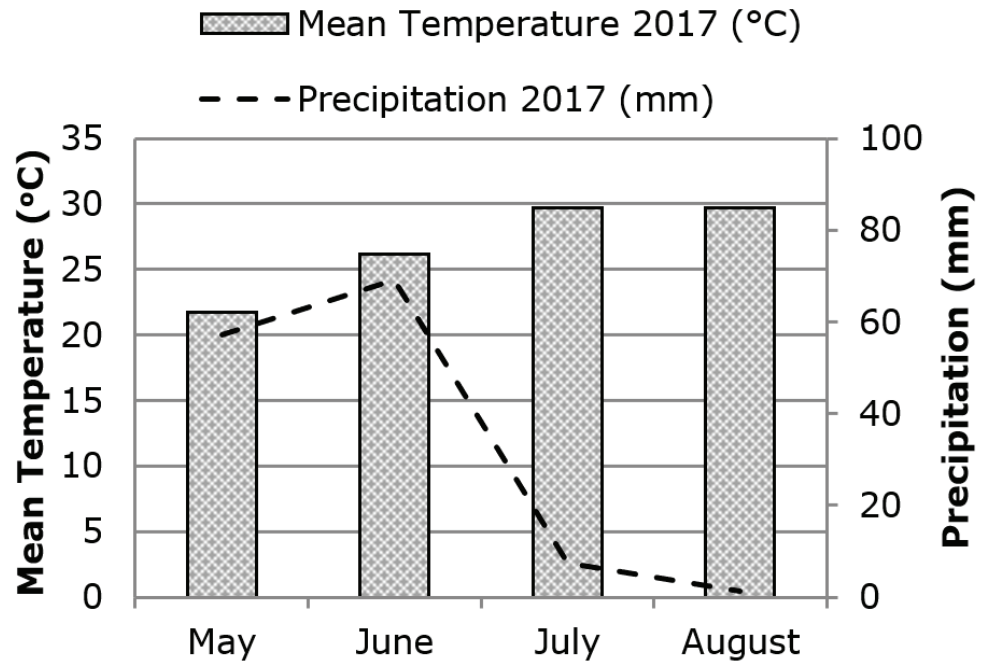

Figure 1. Meteorological data (mean temperature and precipitation) during the growing period (May-August 2017)

agriculture is affected by climate change but also because agriculture, as it is now practiced is a part of the problem (IPCC, 2011). That means that a lot of changes and adaptations have to be done in order to adjust to the new global situation. On one hand, one solution to adapt to climate change is to introduce new crops in new climate zones as the climatic situations are changing rapidly. Some examples are shown to be already possible in the Mediterranean area (Bilalis et al., 2017). On the other hand, the existing agricultural practices should be reconsidered so that agriculture could be a very important key to mitigate the production of greenhouse gases but also to absorb permanently greenhouse gases from the atmosphere. Organic agriculture could become a crucial key to stimulate the agricultural sector to adapt more sustainable practices as it is called out with the Organic 3.0 project of IFOAM (Albenez, 2016).

One good example to show that a different approach in the agricultural system is possible is the Biocyclic Vegan Standard that has been integrated into the global part of the IFOAM's Family of Standards since 2017 (IFOAM, 2018; The International Biocyclic Vegan Network, 2019). One of the important differences and new introductions in the agricultural system is the usage of humus soil. Humus soil is a stabilized plant-based compost which has gone through a post maturing process and is an apparently carbon stabilized form of organic matter with absents of water-soluble nutritional elements and high water capacity capable to be used in direct content with the root system of any kind of plant independent of the age of the plant and the stage of development. Due to its stabilized amorph carbon grid structure, biocyclic humus soil ensures the permanent reservation of $\mathrm{CO}_{2}$ in the form of organic matter and the permanent rise of agricultural soils fertility (BNS, 2018).

The purpose of this study is to evaluate the effect of biocyclic humus soil in field conditions of a processing tomato crop on yield and some quality parameters which are important for the processing tomato industry.

\section{Materials and methods}

A field experiment was accomplished at the Agricultural University of Athens (Latitude: $37^{\circ} 59^{\prime}$ $1.70^{\prime \prime} \mathrm{N}$, Longitude: $23^{\circ} 42^{\prime}$ 7.04" E, Altitude: $30 \mathrm{~m}$ above sea level) from May until August of 2017. The texture of the experimental field soil was clay loam $(29.8 \%$ clay, $34.3 \%$ silt and $35.9 \%$ sand) with a pH of $7.29\left(1: 1 \mathrm{H}_{2} \mathrm{O}\right)$ and chemical components as follow, nitrate-nitrogen $\left(\mathrm{NO}_{3}-\mathrm{N}\right)$ $12.4 \mathrm{mg} \mathrm{kg}^{-1}$ soil, available phosphorus (P) 13.2 mg kg-1 soil, available potassium (K) $201 \mathrm{mg} \mathrm{kg}^{-1}$ soil, $15.99 \% \mathrm{CaCO}_{3}$ and $1.47 \%$ organic matter. The meteorological data during the experimental period were obtained from the weather station of Agricultural University of Athens as are shown in Figure 1.

Seedlings of the processing tomato hybrid Heinz 3402 were used for this trial and were transplanted on $5^{\text {th }}$ of May 2017. The soil was prepared by ploughing at a depth of $0.25 \mathrm{~m}$ and the experiment was arranged in a Completely Randomized Design with three replications and three fertilization treatments untreated-control (CON), inorganic fertilizer (IN) and biocyclic 
Table 1. Analysis of Biocyclic Humus Soil on dry mass and in water extraction

\begin{tabular}{ccc}
\hline Analysis description & Dry mass & $\begin{array}{c}\text { Extraction with 600 ml deionized } \\
\text { water from 360g humus soil }\end{array}$ \\
\hline Total Nitrogen (N) g/100g & 2.8 & 0.015 \\
\hline $\mathrm{P}_{2} \mathrm{O}_{5}$ Soluble in inorganic acids (total) g/100g & 0.8 & 0.002 \\
\hline Total Potassium (K) g/100g & 0.6 & 0.034 \\
\hline Electrical Conducitivity (1:5) pH units & 7.6 & \\
\hline Cation Exchange Capacity (C.E.C.) meq Na/100g & 91.9 & \\
\hline
\end{tabular}

humus soil (HS). Every plot had a size of $2 \mathrm{~m}$ x 3.6 $\mathrm{m}$. In each plot, 30 seedlings were transplanted at a spacing of $0.6 \mathrm{~m} \times 0.4 \mathrm{~m}$. One day before tomato transplanting, 340 gr of the inorganic fertilizer (42-0-0) was applied manually, which is equivalent with $200 \mathrm{~kg} \mathrm{~N} / \mathrm{ha}$. The biocyclic humus soil was incorporated into the planting rows with 40 liters in each, which is 8 liters for each plant. A drip irrigation system was also set up on the field. The total quantity of water applied during the cultivation period was $712 \mathrm{~mm}$. All plots were irrigated with the same amount of water. The biocyclic humus soil which was used in this experiment is made from $100 \%$ plant materials and mostly from byproducts from olive oil mills. The raw materials were $50 \%$ olive leaves, $30 \%$ olive pomace, $10 \%$ grape pomace and $10 \%$ ripe humus soil. First, an aerobe composting process was followed in rows with a height of $1.5 \mathrm{~m}$ and a width of $2.5 \mathrm{~m}$. A compost windrow turner was used to obtain the aeration and hydration of the raw materials. After 5 to 6 months of composting process a ripe compost of substrate quality was achieved. To turn the ripe compost into humus soil, a ripening process of three years followed. The outcoming material is beyond the substrate maturity and has a more soil-like structure suitable for direct planting. As shown in Table 1, the high content and availability of nutrients are combined with no water solubility of these nutrients.

Tomato plants were harvested 116 days after transplanting. The total fruit yield was determined by using four randomly chosen plants from each plot. The qualitative parameters were assessed using three fruits per plant from three randomly selected plants per plot.

For measuring the fruit firmness, a dedicated force gauge tester Chatillon DFIS 10 with the stand of Chatillon TMC 201 were used with a capacity of $50 \mathrm{~N}$ and an accuracy of $0.1 \mathrm{~N}$. The travel speed was $200 \mathrm{~mm} / \mathrm{min}$ and the conical needle had a diameter $6.3 \mathrm{~mm}$. The Total Soluble Solids
(TSS) were determined at $20^{\circ} \mathrm{C}$ with a handheld refractometer Schmidt \& Hänsch HR32B having a sensitivity of $0.2^{\circ} \mathrm{Bx}$. Titratable Acidity (TA) was obtained by titrating $50 \mathrm{ml}$ of diluted tomato pulp with $0.2 \mathrm{~N} \mathrm{NaOH}$ using a $1 \%$ phenolphthalein solution.

The experimental data analysis was subjected to statistical analysis according to the completely randomized design (CRD) using the Statistica 7.0 statistical software. Differences between means were separated using the least significant difference (LSD) test. Correlation analyses were used to describe the relationships between yield and quality characteristics using Pearson's correlation. All comparisons were made at the 5\% level of significance.

\section{Results and discussions}

The fruit yield of processing tomato for the biocyclic humus soil treatments was $116.8 \mathrm{t} \mathrm{ha}^{-1}$ in comparison to 80.6 and $63 \mathrm{t} \mathrm{ha}^{-1}$ for the inorganic fertilizer treatment and the control, respectively. These results show a statistical difference $(\mathrm{F}=$ $3.43, \mathrm{p}=0.011$ ). This means that the total yield of processing tomatoes grown in plots treated with biocyclic humus soil was $45 \%$ more than the conventional yields (Fig. 2). As the roots of the processing tomato plants were in direct contact with humus soil, they could absorb all the nutrients they needed, and due to the porous structure of humus soil, the roots could expand more than the roots of the plants which were in contact only with the field soil. The big difference in yield can also be explained due to the better water capacity of humus soil in comparison with the clay loam experimental soil and that's why the plants could resist more to high temperatures thus coping more easily with summer and water stress situations which can cause lower yields (Pék et al., 2014; Lovelli et al., 2016).

According to the study of Maienza et al. (2014), a biochar treatment shows a better first 


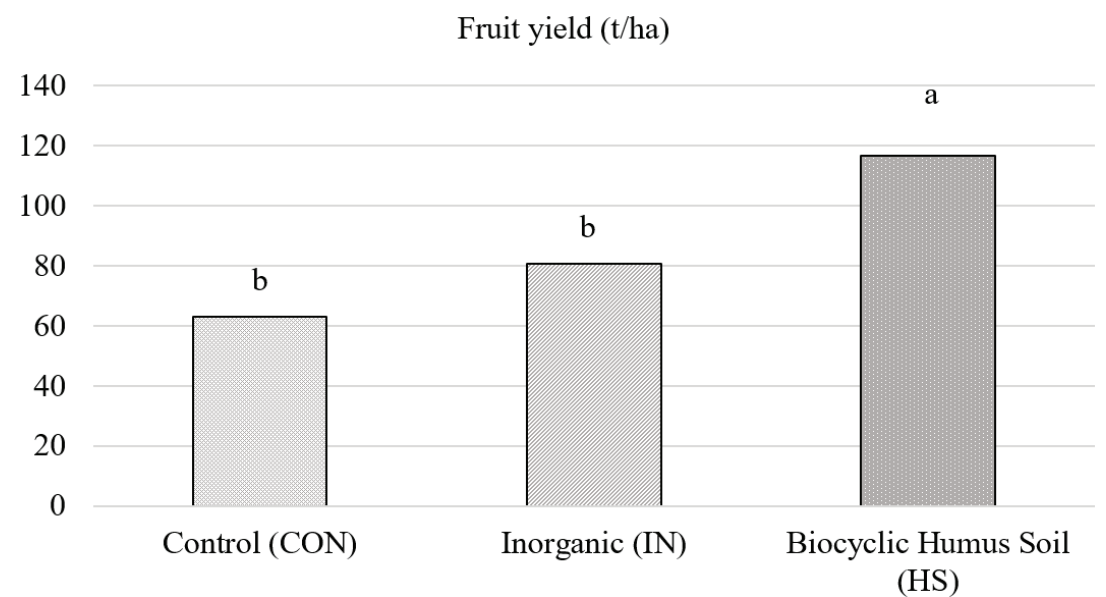

Figure 2. Fruit yield of processing tomato ( $\mathrm{t} / \mathrm{ha}$ ) as affected by fertilization. Different low-case letters denote statistically significant differences $(\mathrm{p} \leq 0.05)$.

Table 2. Effect of fertilization (Control, NPK, Biocyclic humus soil) on total soluble solids (TSS), titratable acidity (TA) and fruit firmness by LSD test.

\begin{tabular}{lccc}
\hline Fertilization & $\begin{array}{c}\text { Total Soluble Solids } \\
(\mathrm{TSS})\left({ }^{\circ} \mathrm{Brix}\right)\end{array}$ & $\begin{array}{c}\text { Titratable Acidity (TA) } \\
(\mathrm{g} \text { citric acid } / 100 \mathrm{~g} \text { fruit })\end{array}$ & $\begin{array}{c}\text { Fruit firmness } \\
\left(\mathrm{kg} \mathrm{cm}^{-2}\right)\end{array}$ \\
\hline Control (CON) & $4.29 \mathrm{a}$ & $0.26 \mathrm{a}$ & $4.60 \mathrm{a}$ \\
Inorganic (IN) & $4.59 \mathrm{a}$ & $0.25 \mathrm{a}$ & $4.34 \mathrm{a}$ \\
Biocyclic humus soil (HS) & $4.76 \mathrm{a}$ & $0.31 \mathrm{a}$ & $4.51 \mathrm{a}$ \\
$F_{\text {fertilization }}$ & $\mathrm{ns}$ & $\mathrm{ns}$ & $\mathrm{ns}$ \\
\hline Different letters within a column indicate significant differences test $(\mathrm{p}=0.05)$. Significance levels: ${ }^{*} \mathrm{p}<0.05$; ns, not significant (p \\
$>0.05)$.
\end{tabular}

vegetation period of processing tomato plants without affecting the end yields. A positive correlation between final yields of processing tomatoes and humic acid treatments were shown with different doses of humic acids (Asri et al., 2015). Lower total yield in organic than in conventional processing tomatoes was shown by Ronga et al. (2017). No differences in total yield between different cultivation systems were achieved from Rinaldi et al. (2007) and Boček et al. (2008) but also with treatments with effective microorganisms (Ratajkiewicz et al., 2017).

The high content of Total Soluble Solids (TSS) in processing tomatoes is very important for the processing industry because it reduces the time and the costs for preparation (Hewitt et al., 1982). In this experiment, the TSS for the tomatoes grown in humus soil was $4.76^{\circ} \mathrm{Bx}$ in comparison with $4.59^{\circ} \mathrm{Bx}$ for the inorganic treatment and 4.29 ${ }^{\circ} \mathrm{Bx}$ for the control without statistically significant differences (Tab. 2). Similar results have also been reported by Boček et al. (2008) in an experiment with different organic fertilizers or by Asri et al. (2015) after using fertilizers with humic acids. In the field experiment of Pieper and Barrett
(2009), a higher TSS concentration in processing tomatoes grown organically in comparison with conventional treatments were shown.

Statistically, there were no differences between treatments, for the Titratable Acidity (TA) which is an important parameter for the longer conservation of processing tomato products, with the values being $0.31 \mathrm{~g}$ citric acid $/ 100 \mathrm{~g}$ fruit weight for the humus soil treatment and $0.25 \mathrm{~g}$ and 0.26 g citric acid/100g fruit weight for the inorganic treatment and the control, respectively. Asri et al. (2015) found a positive correlation between the treatments with different concentrations of humic acids with the higher TA concentration at $0.37 \mathrm{~g}$ citric acid $/ 100 \mathrm{~g}$ fruit weight with a dose of 160 liters humic acids per hectare. In the experiment of Leiva-Brondo et al. (2015), the content of glucose and fructose was $10 \%$ higher for the organic treatments than the conventional. Moreover, the fruit firmness which is one of the most important quality parameters of the tomatoes processed by the canning industry, was also not affected by different treatments (Tab. 2); however, the higher values were found in control $\left(4.60 \mathrm{~kg} \mathrm{~cm}^{-2}\right)$ and biocyclic humus soil $\left(4.51 \mathrm{~kg} \mathrm{~cm}^{-2}\right)$. In general, 
Table 3. Correlation coefficient between yield and quality parameters

\begin{tabular}{|c|c|c|c|}
\hline \multirow{2}{*}{ Property } & \multicolumn{3}{|c|}{ Coefficient of Correlation } \\
\hline & Fruit yield & Fruit firmness & TSS \\
\hline Fruit firmness & $0.2633^{\mathrm{ns}}$ & & \\
\hline TSS & $0.4875^{\mathrm{ns}}$ & $-0.4962^{\mathrm{ns}}$ & \\
\hline TA & $0.6609^{\mathrm{ns}}$ & $0.3009^{\text {ns }}$ & $0.6189^{\mathrm{ns}}$ \\
\hline
\end{tabular}
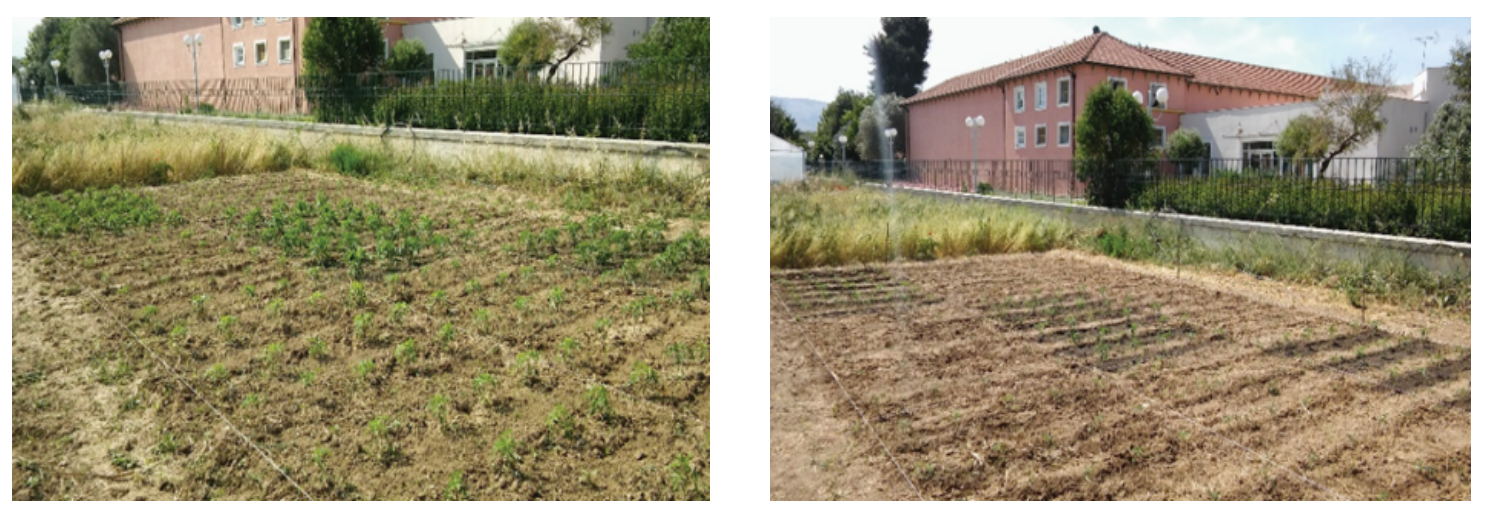

Picture 1 (left) \& 2 (right). Processing tomato field at 10 and 20 days after transplanting, respectively
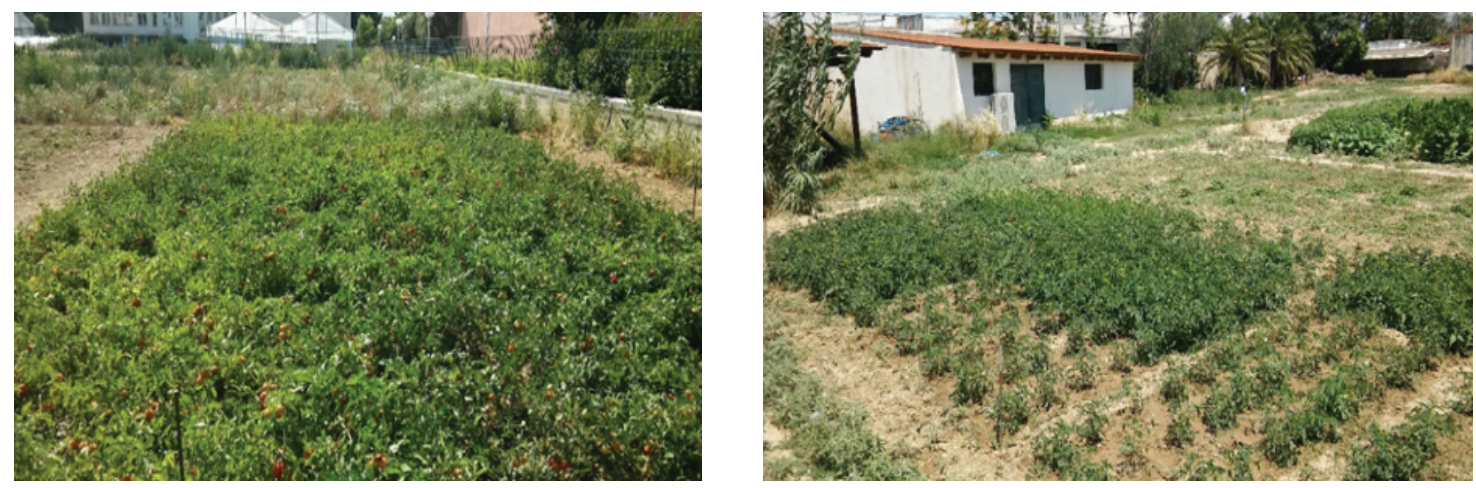

Picture 3 (left) \& 4 (right). Processing tomato field at 42 and 82 days after transplanting, respectively

fruit firmness is negatively correlated with the increase of nitrogen content in fruits (Knee, 2002). As shown in Table 3, there were no correlations between fruit yield and the quality parameters.

During this research, as shown in Pictures 1-4, it was also observed that the vegetation of plants in the plots with biocyclic humus soil (diagonal) was quicker and stronger from the beginning till the end of the growing season which affected the blooming and final yields.

\section{Conclusions}

In this experiment, the tomato plants grown in biocyclic humus soil had $45 \%$ more yield than in conventional plots. There were no differences on the quality parameters of the tomato fruits between the different treatments. After the end of growing season, the plants were totally removed from the field, but the humus soil was still fully visible within the planting rows, which means that the applicated quantity of humus soil could be used again for the following cultivation or the next production period. In real field conditions, this could have a very important economic impact for producers to use the same input for many growing seasons and vegetation periods. The stabilized carbon structure which seems to occur in a very mature compost like humus soil could also have a significant environmental impact as $\mathrm{CO}_{2}$ originating from organic matter is bound in a stable soil-like form into the soil. The molecule carbon structure which seems to be built in humus soil could explain some of the special characteristics that have been observed by using humus soil as a direct substrate for plant growing. 
Of course, a lot of research has to be done in order to prove this hypothesis.

Acknowledgments Special thanks to the D. Nomikos S.A. company for providing the processing tomato seedlings, as well as the Biocyclic Park in Kalamata, Greece, for providing the biocyclic humus soil used in this trial.

\section{References}

1. Arbenz M, Gould D, Stopes C (2016). Organic 3.0 - for truly sustainable farming and consumption. Bonn: IFOAM Organics International.

2. Asri F O, Demirtas EI, Ari N (2015). Changes in fruit yield, quality and nutrient concentrations in response to soil humic acid applications in processing tomato. Bulgarian Journal of Agricultural Science, 21(3): 585-591.

3. Bark J, Pék Z, Helyes L, Posta K (2018). Mycorrhizal inoculation alleviates water deficit impact on field-grown processing tomato. Polish Journal of Environmental Studies, 27(5): 1949-1958

4. Bilalis D, Roussis I, Fuentes F, Kakabouki I, Travlos I (2017). Organic agriculture and innovative crops under Mediterranean conditions, Notulae Botanicae Horti Agrobotanici Cluj-Napoca, 45(2): 323-331.

5. Biocyclic Network Services Ltd. (BNS). Was sind die Biozyklischen Standards? (2018). http://www.biocyclicnetwork.net/die-biozyklischen-standards.htmlAccessed 01.09.2018.

6. Boček S, Malý I, Patočková Š (2008). Yield and quality of bush processing tomatoes fertilized with dried organic and organomineral fertilizers. Acta Universitatis Agriculturae et Silviculturae Mendelianae Brunensis, 56(2): 31-37.

7. Food and Agriculture Organization of the United Nations, FAOSTAT statistics database. (2018). http://www.fao. org/faostat/en/\#data/QC Accessed 03.01.2018.

8. Hewitt JD, Dinar M, Stevens M A (1982). Sink strength of fruits of two tomato genotypes differing in total fruit solids content. Journal of the American Society for Horticultural Science, 107: 896-900.

9. International Federation of Organic Agricultural Movements (IFOAM), Organic IFOAM Family of Standards, That's Organic-Worldwide. (2018). http://www.ifoam. bio/sites/default/files/familyframe_web_2.pdf Accessed 01.09.2018.

10. International Panel on Climate Change IPCC. (2011). www.ipcc.ch/pdf/assessment-report/ar5/wg3/ ipcc wg3_ar5_chapter11.pdf Accessed 04.03.2018.

11. Knee M (2002). Fruit quality and its biological basis. Sheffield Academic Press, Sheffield, UK.

12. Le TA, Pek Z, Takacs S, Nemenyi A, Daood HG, Helyes L (2018a). The effect of plant growth promoting rhizobacteria on the water-yield relationship and carotenoid production of processing tomatoes. HortScience, 53(6): 816-822.
13. Le TA, Pek Z, Takacs S, Nemenyi A, Helyes L (2018b). The effect of plant growth-promoting rhizobacteria on yield, water use efficiency and Brix Degree of processing tomato. Plant, Soil and Environment, 64(11): 523-529.

14. Leiva-Brondo M, Martí R, Macua JI, Lahoz I, González A, Campillo C, Roselló S, Cebolla-Cornejo J (2015). Sugar and acid profile of processing tomato cultivars grown under conventional or organic conditions. Acta Horticulturae, 1081: 181-186.

15. Lovelli S, Potenza G, Castronuovo D, Perniola M, Candido V. (2016). Yield, quality and water use efficiency of processing tomatoes produced under different irrigation regimes in Mediterranean environment. Italian Journal of Agronomy, 12: 795.

16. Maienza A, Genesio L, Acciai M, Miglietta F, Pusceddu E, Vaccari F (2017). Impact of Biochar Formulation on the Release of Particulate Matter and on Short-Term Agronomic Performance. Sustainability, 9: 1-10.

17. Miyao G, Hartsough B (2010). History of mechanized harvesting of processing tomatoes in California, In: Annual Conference of the American Society for Horticultural Science, California, U.S.A., 2-5 August 2010.

18. Pék Z, Helyes L, Lugasi A, Daood H. (2014). The simultaneous effect of water supply and genotype on yield quantity, antioxidants content and composition of processing tomatoes. Notulae Botanicae Horti Agrobotanici Cluj-Napoca, 42: 143-149.

19. Pieper R, Barrett D (2009). Effects of organic and conventional production systems on quality and nutritional parameters of processing tomatoes. Journal of the Science of Food and Agriculture, 89: 177-194.

20. Ratajkiewicz H, Radziejewska-Kubzdela E, Spiżewski T, Krzesinski W, Starzyk J, Biegańska-Marecik R, Gaj R, Piekarczyk J (2017). The influence of "Effective Microorganisms" and solar radiation on carotenoids and phenolic compounds content in processing tomato. European Journal of Horticultural Science, 82: 134-140.

21. Rinaldi M, Convertini G, Elia A (2007). Organic and mineral fertilization for processing tomato in Southern Italy. Acta Horticulturae, 758:241-247.

22. Ronga D, Zaccardelli M, Lovelli S, Perrone D, Francia E, Milc J, Ulrici A, Pecchioni N (2017). Biomass production and dry matter partitioning of processing tomato under organic vs conventional cropping systems in a Mediterranean environment. Scientia Horticulturae, 224: 163-170.

23. The International Biocyclic Vegan Network. The Biocyclic Vegan Standard (English) (2019). http://www.biocyclicvegan.org/wp-content/uploads/2019/01/BIOCYCLICVEGAN-STANDARDS-2017.pdf Accessed 25.03.2019.

24. World Processing Tomato Council (WPTC). World Production Estimate of Tomatoes for Processing. (2018). http://www.wptc.to Accessed 03.02.2018. 